\title{
Efficiency of Rhizobium strains as plant growth promoting rhizobacteria on morpho-physiological properties of Brassica napus L. under salinity stress
}

\author{
Davood Saghafi ${ }^{1}$, Manour Ghorbanpour ${ }^{2 *}$, Behnam Asgari Lajayer ${ }^{3}$
}

${ }^{1}$ Department of Agriculture, Miandoab Branch, Islamic Azad University, Miandoab, Iran. ${ }^{2}$ Department of Medicinal Plants, Faculty of Agriculture and Natural Resources, Arak University, Arak, Iran. ${ }^{3}$ Young Researchers and Elite Club, Tabriz Branch, Islamic Azad University, Tabriz, Iran.

*Corresponding author: m-ghorbanpour@araku.ac.ir

\begin{abstract}
Soil Salinity stress has been considered as one of the most severe environmental factors limiting the agricultural production worldwide. This study was aimed to evaluate the influence of plant growth promoting Rhizobium bacteria treatments $(\mathrm{T} 1=$ without bacteria inoculation, T2=strain Sm29, T3=strain Sm103, T4=strain Rlp307, T5=strain Rlp281, T6=strain Rlp258, T7=strain Rlp266) on morpho-physiological parameters of canola (Brassica napus L.) under salinity stress (0, 3, 6 and $9 \mathrm{ds} / \mathrm{m})$. Experimental treatments were performed as factorial in a Randomized Complete Block Design $(\mathrm{RCBD})$ with three replications $(\mathrm{n}=3)$. Inoculation with halotolerant bacteria containing ACC-deaminase activity, IAA producing and mineral phosphate-solubilizing properties (i.e., T5) showed significant $(\mathrm{p}<0.05)$ effect on growth indices, especially plant height and dry weight of the shoot with an increase of 35 and $26 \%$ in comparison with the control, respectively. However, T4 treatment with ACC deaminase-producing halotolerant and IAA producing bacteria was more efficient in increasing dry weight of the root (up to 56.5\%). Moreover, Inoculation with bacteria that have more growth promoting attributes (e.g., ACC-deaminase activity, IAA producing and mineral-phosphate solubilizing attributes) was found to be highly promising under saline environment and can be taken up for the further field level testing.
\end{abstract}

Keywords: Brassica napus L., Morpho-physiological traits, Rhizobium bacteria, Salinity stress, IAA, ACCdeaminase 


\section{Introduction}

Canola (Brassica napus L.) is one of the most important oil-bearing crops and considered as the most promising oil source characterized with high seed oil content (40-45\%) worldwide (Ministry of Agriculture, 2012). Also, because of its capability to cultivation in various regions, the high percentage and the desired quality of the oil is considered as a promising energy crop for crude oil production. The increase in global average per capita oil consumption has increased the cultivation of oil seed crop as a key source of lipids for human nutrition, and the scientific researches on these products has gained increased attention (Ministry of Agriculture, 2012). However, the increase of plant productions has coincided with the decrease in cultivable croplands area due to the limitations of water and soil. Agronomical techniques such as irrigation, drainage, and fertilization can prevent water and soil salinization and alleviate the adverse effects of salinity.

Today's, expanding crop production is one of the main challenges of agriculture. Increasing production in the modern agriculture is extensively dependent upon the optimum use of chemical fertilizers and other inputs, given that using these types of fertilizers triggers even more salinity in addition to high charges, low efficiency, and high risk of environmental pollution (Piranooshe et al., 2011). Therefore, gradual replacement of chemical fertilizers with organic and biological fertilizers due to some relative advantages such as lack of concern over environmental issues, improve soil fertility, and costeffective (i.e., reduces the costs toward fertilizers use particularly regarding nitrogen and phosphorus) is considered an efficient step towards sustainable development goals (Piranooshe et al., 2011).

Rhizobium bacteria are among the most beneficial soil bacteria, which known as biological fertilizer, whose members are most notable for their ability in N2 fixation, and ability to generate plant growth promoting substances, and also because of the existence of technology having the potential to mass production of inoculants (Sessitsch et al., 2002).

Researches about the positive impacts of Rhizobium bacteria on non-leguminous plants is relatively new, and the most studies reveal that these bacteria may have beneficial effects on non-legume species including rice (Hussain et al., 2009), maize (Matiru and Dakora, 2004), wheat and canola (Shakhavat and Martensson, 2007). The positive effect on plant growth and development following inoculation with rhizobacteria in non-legume crops is related to various mechanisms other than the formation of root nodule and the biological fixation of $\mathrm{N} 2$ (Hussain et al., 2009). Chi et al. (2005) reported that inoculation of rice (Oryza sativa L.) with Rhizobium bacteria increased plant height, weight of the root and shoot, photosynthesis rate, stomatal conductance, Irrigation water use efficiency, absorption of nutrients, and extension of leaf area compared to the control. Production of Indole-3-acetic acid (IAA) and gibberellin has been described as the main reason for increasing plant growth and productivity caused by Rhizobium bacteria exposure (Chi et al., 2005). The study by Singh et al. (2005) revealed that plant height and fresh and dry weights of the rice increased by $6.9,45.51$ and $18.6 \%$ compared to the control, respectively, due to inoculation by Rhizobium bacteria. The same authors reported that the solubilizing of phosphate, and the production of growth regulators were the main reasons for improving plant growth traits. Growth promoting effects of Rhizobium bacteria emphasize the efficiency of some of the Rhizobium strains as plant growth promoting rhizobacteria (PGPRs) and the possibility of using them in cultivating non-legume 
plants (Alikhani et al., 2004), and is also evidence of the necessity of using native Rhizobium inoculants in agricultural soils. Therefore, it is expected that studies on native strains should result in mass production of microbial inoculants that are more efficient for local crop products.

Regarding to the significance of canola in the self-containment programs of the developing countries in the area of acquiring oil, and also the international approach in reserving the natural resources by reducing the use of chemical fertilizers, application of PGPR can be a valuable tool in sustainable agricultural systems. Therefore, the present study was aimed to examine the effects of Rhizobium strains on morphological characteristics of a non-legume plant canola under salinity stress condition.

\section{Materials and Methods}

\subsection{Plant materials and growing conditions}

To study the interaction between canola and Rhizobium strains under salinity stress a greenhouse experiment was performed with three replications.
Soil samples were randomly collected from surface to $25 \mathrm{~cm}$ in depth at the around of Karaj, Iran. Physical and chemical properties as well as nutrients status were determined in samples after air-drying and passing through $2 \mathrm{~mm}$ sieve [hydrometer method for texture, field capacity by pressure plates, organic matter by valkli black method, calcium carbonate by calcimetry method, nitrogen through kejeldal method, phosphorus by olsen method (Gupta, 2000), and potassium by using ammonium acetate) (Table 1). The nutritional requirement of the plant was provided based on the fertilizer recommendations. In the next step, $5 \mathrm{~kg}$ of soil was measured and put in each pot. In this experiment, the RGS003 cultivar of canola which provided from the Seed and Improvement Institute Karaj (Iran) was used. Five seeds were cultivated in each pot, and then suspension of the selected Rhizobium strains (1 mL) was inoculated to each germinated seed. The negative control (T1) treatment was Yeast extract Mannitol Agar (YMA) medium without bacteria. After the emergence, the weakest seedlings thinned to two in each pot.

Table 1. Properties of the selected soil used in this study

\begin{tabular}{cccc}
\hline Soil characteristics & Value & Soil characteristics & Value \\
\hline Sand $(\%)$ & 39 & Total N $(\%)$ & 0.053 \\
Silt (\%) & 36 & Available P $(\mathrm{mg} / \mathrm{kg})$ & 5.6 \\
Clay (\%) & 25 & Available $\mathrm{K}(\mathrm{mg} / \mathrm{kg})$ & 230 \\
Soil texture class & loam & $\mathrm{Na}(\mathrm{meq} / \mathrm{l})$ & 2 \\
$\mathrm{Fc}(\%)$ & 16 & $\mathrm{Fe}^{*}$ & 1.67 \\
$\mathrm{pH}$ & 8.10 & $\mathrm{Zn} *$ & 1.38 \\
$\mathrm{EC}$ & 1.28 & $\mathrm{Mn}^{*}$ & 3.57 \\
$\mathrm{OM}(\%)$ & $\mathrm{Cu}^{*}$ & 1.61 \\
$\mathrm{CaCO}_{3}(\%)$ & 0.075 & Total microbial population (cfu/gr.soil) & $2.5 * 10^{4}$ \\
\hline
\end{tabular}


Exposure to salinity stress was done for the all treatments after two weeks of seed germination using the mixture solution of $\mathrm{NaCl}$ and $\mathrm{MgCl}_{2}$. Before the irrigation of the pots with saline water, three control pots were dedicated to each level of salinity by adding gradually salt water (in eight steps, each time $200 \mathrm{~mL}$ ) to the pots and the electrical conductivity of experimental soil was measured accordingly. Temperature of the greenhouse was adjusted in the range of 24-32 ${ }^{\circ} \mathrm{C}$ during the growth period, and the light was provided by a combination of white and yellow halogen lights intermittently placed with the average of 13000 lux, and with a lighting period of $14 \mathrm{~h}$ a day.

\subsection{Experimental set up and treatments}

The experimental treatments were considered as follows: 1) Salinity stress at four levels (0, 3, 6 and 9 $\mathrm{ds} / \mathrm{m})$; and 2) inoculation with Rhizobium bacteria (T1=without bacteria inoculation, $\mathrm{T} 2=$ strain $S m 29$, T3=strain $S m 103 ， \quad \mathrm{~T} 4=$ strain $R l p 307, \quad \mathrm{~T} 5=$ strain Rlp281, T6=strain Rlp258, T7=strain Rlp266). Rhizobium bacteria (the numbers 29 and 103 belonging to Sinorhizobium mellilote and the numbers 307,281 ,
258 and 266 belonging to Rhizobium legominozaroum b.v phaseoli) were prepared from Gene Bank of Soil Science Department in Tehran University. Some of the growth-stimulating properties of applied Rhizobium bacteria were evaluated for greenhouse cultivation (Table 2). The resistance of the different strains against salinity in YMA was measured with a compound of $\mathrm{NaCl}$ and $\mathrm{MgCl}_{2}$. A quantity test of IAA production ability was assayed in DF media (Salt Minimal Medium) (Patten and Glick, 2002), a quality test of ACC-deaminase enzyme production was carried out on the Rhizobial Minimal Medium (RMM) and colony diameter of isolates on RMM + ACC media greater than that of positive control medium $(\mathrm{RMM}+\mathrm{NH} 4 \mathrm{Cl})$ was selected as superior isolates (Penrose and Glick, 2001) and the quantity test of solublization of insoluble phosphates in the cultivation environment of Sperber liquid was done according to the yellow method (Jeon et al., 2003). Therefore, to prepare the inoculants of the selected strains, the bacteria were shaken for $48 \mathrm{~h}$ in a temperature of $28{ }^{\circ} \mathrm{C}$ on the culture medium of YMB. Then, the bacterial suspension was adjusted turbidimetrically to approximately $4 \times 10^{9} \mathrm{cfu} \cdot \mathrm{mL}^{-1}$.

Table 2. The PGPRs characteristics of different strains used in this experiment.

\begin{tabular}{|c|c|c|c|c|}
\hline Strain & Resistance to salinity* & $\mathrm{IAA}\left(\mu \mathrm{g} \mathrm{ml}^{-1}\right)$ & ACC-deaminase & $\begin{array}{l}\text { Dissolution of mineral } \\
\text { phosphate }\left(\mu \mathrm{g} \mathrm{ml}^{-1}\right)\end{array}$ \\
\hline Rlp281 & Resistance & 10.2 & + & 128 \\
\hline Rlp307 & Resistance & 10.2 & + & - \\
\hline$S m 103$ & Resistance & - & + & 98 \\
\hline $\operatorname{Sm} 29$ & Resistance & - & - & 155 \\
\hline$R l p 258$ & Resistance & - & - & - \\
\hline Rlp266 & Sensitive & - & - & - \\
\hline
\end{tabular}

\footnotetext{
*Sensitive: unable to growth up $10 \mathrm{dS} / \mathrm{m}$ of salinity, Resistance: able to growth in $40 \mathrm{dS} / \mathrm{m}$ of salinity.

+: with ACC deaminase enzyme activity

-: without ACC deaminase enzyme activity
} 


\subsection{Measurement of traits}

Plants were harvested after 4.5 month of growth and the following characteristics were measured: Plant height, leaf area index, chlorophyll content (SPAD reading), fresh and dry weights of the root and shoot. Moreover, after providing the plant extracts by dry ashing method, the concentration of phosphorus (P) in the shoot was measured based on Yellow method, and concentration of potassium $\left(\mathrm{K}^{+}\right)$was determined thorough Flame photometer procedure (Gupta, 2000). Also, relative water content (RWC) was calculated on leaf tissues obtained from the forth fully developed undamaged leaf at the top of the plant. They were immediately sealed into plastic bags and fresh weights were measured after samples transferred to laboratory. Then, they were submerged in distilled water in test tubes for $6 \mathrm{~h}$ at room temperature and the turgor weight was estimated accordingly. Dry weight was measured after drying the leaf samples in electrical oven at $70{ }^{\circ} \mathrm{C}$ for $48 \mathrm{~h}$. Thereafter, RWC (\%) was determined through the following formula (Bertamini et al., 2006):

$R W C=\frac{\text { Fresh weight }- \text { Dryweight }}{\text { Turgor weight }- \text { Dryweight }} \quad$ Formulal

\subsection{Statistical analysis}

Data were processed by the analysis of variance (ANOVA) based on completely Randomized Blocks Design (CRBD) with factorial experiment in three replications. The data were analyzed using computer SAS software (version 9.1; CoHort Software), and the analysis of means (ANOM) were compared by Duncan's Multiple Range Test (DMRT) at $p<0.05$.

\section{Results}

Based on the analysis of variance results, the main effect of bacteria and salinity stress was significant $(p<0.01)$ on all the measured characteristics. The interaction effects of bacteria and salinity on chlorophyll content, leaf relative water content, leaf area index and potassium concentration were not significant, however, plant height, dry weight of the shoot and root, root to shoot dry weight ratio $(\mathrm{R} / \mathrm{S})$ and phosphorous concentration were significantly $(p<0.01)$ affected (Table 3$)$ by the experimental treatments.

\subsection{The effect of PGPR on physiological traits of canola under salinity stress}

Salinity stress significantly $(p<0.01)$ decreased the average of leaf area index and leaf relative water content. However, the highest value of both previously mentioned traits was observed in S0 (control), and S3 treatments. Also, leaf area index and leaf relative water content showed 38.16 and $19.93 \%$ reduction compared to control, respectively (Table 4). Results showed that the value of chlorophyll index (SPAD) was increased with increasing salinity levels, so that the highest value was found in S3 treatment, in which an increase of $25.38 \%$ was observed, compared to the respective control (Table 4).

Inoculation with bacteria showed that the highest value of leaf area $\left(387 \mathrm{~cm}^{2}\right)$ was obtained in $\mathrm{T} 4$ treatment followed by and T5 $\left(378 \mathrm{~cm}^{2}\right)$, however, the difference between these two treatments was not statistically significant. In general, T4, T5, 53, T6, $\mathrm{T} 2$, and $\mathrm{T} 7$ showed $17.6,14.9,12,11,7.5$ and $4 \%$ of increase in leaf area compared to the control (T1), respectively (Figure 1-A). 
Mean RWC, showed the highest increase (by $8.78 \%$ ) under T5 treatment followed by T4 (8.68\%), also, the difference between these two treatments was not statistically significant. In addition, T3, T6, T2, and T7 increased RWC by $7,5.5,5$, and $2.76 \%$, respectively (Figure 1-B). Regarding the index of SPAD, treatments of T5, T3, and T4 caused a significant increase of $8.34,5.68$, and $3.22 \%$ compared to the control, respectively. The effect of the other treatments was not significant on SPAD reading (Figure 1-C). Based on the result obtained from the interaction effect of bacterium and salinity, the highest and the lowest amount of leaf area index and RWC were observed in T5S0 and T1S3 treatments, respectively (Table 5).

Table 3. Results of analysis of variance (ANOVA) for the effects of bacteria and salinity stress on morphophysiological characteristics and nutrient concentrations in canola (B. napus L.).

\begin{tabular}{ccccccccccc}
\hline \multicolumn{1}{c}{ Source of } \\
Variation
\end{tabular}

$*, * *$ and ns in order significant different at level $5 \%$ and $1 \%$ and non-significant

Table 4. Analysis of mean (ANOM) for the main effect of different levels of salinity stress on morpho-physiological characteristics and nutrient concentrations in canola (B. napus L.).

\begin{tabular}{cccccccccc}
\hline Treatment & $\begin{array}{c}\text { Leaf } \\
\text { area } \\
\left(\mathrm{cm}^{2}\right)\end{array}$ & $\begin{array}{c}\text { RWC } \\
(\%)\end{array}$ & $\begin{array}{c}\text { SPAD } \\
\text { Index }\end{array}$ & $\begin{array}{c}\text { Height } \\
(\mathrm{cm})\end{array}$ & $\begin{array}{c}\text { Dry } \\
\text { Weight of } \\
\text { shoot }(\mathrm{g})\end{array}$ & $\begin{array}{c}\text { Dry } \\
\text { Weight of } \\
\text { Root(g) }\end{array}$ & R/S & P (\%) & K (\%) \\
\hline S0 & $446^{\mathrm{a}}$ & $8412^{\mathrm{a}}$ & $44.9^{\mathrm{d}}$ & $66.69^{\mathrm{a}}$ & $25.36^{\mathrm{a}}$ & $3.19^{\mathrm{a}}$ & $0.125^{\mathrm{a}}$ & $0.21^{\mathrm{a}}$ & $2^{\mathrm{d}}$ \\
$\mathrm{S} 1$ & $382^{\mathrm{b}}$ & $77.94^{\mathrm{b}}$ & $48^{\mathrm{c}}$ & $54.5^{\mathrm{b}}$ & $22.76^{\mathrm{b}}$ & $2.3^{\mathrm{b}}$ & $0.1^{\mathrm{b}}$ & $0.18^{\mathrm{b}}$ & $2.17^{\mathrm{c}}$ \\
$\mathrm{S} 2$ & $338^{\mathrm{c}}$ & $72.68^{\mathrm{c}}$ & $51.6^{\mathrm{b}}$ & $46.3^{\mathrm{c}}$ & $20.6^{\mathrm{c}}$ & $1.97^{\mathrm{c}}$ & $0.095^{\mathrm{b}}$ & $0.17^{\mathrm{c}}$ & $2.29^{\mathrm{b}}$ \\
$\mathrm{S} 3$ & $276^{\mathrm{d}}$ & $64.19^{\mathrm{d}}$ & $56.3^{\mathrm{a}}$ & $36.6^{\mathrm{b}}$ & $17.3^{\mathrm{d}}$ & $1.57^{\mathrm{d}}$ & $0.09^{\mathrm{c}}$ & $0.16^{\mathrm{d}}$ & $2.46^{\mathrm{a}}$ \\
\hline
\end{tabular}

Means in each column with at least one similar letters are not significantly different at the $5 \%$ probability level using Duncan Multiple Range Test (DMRT). 

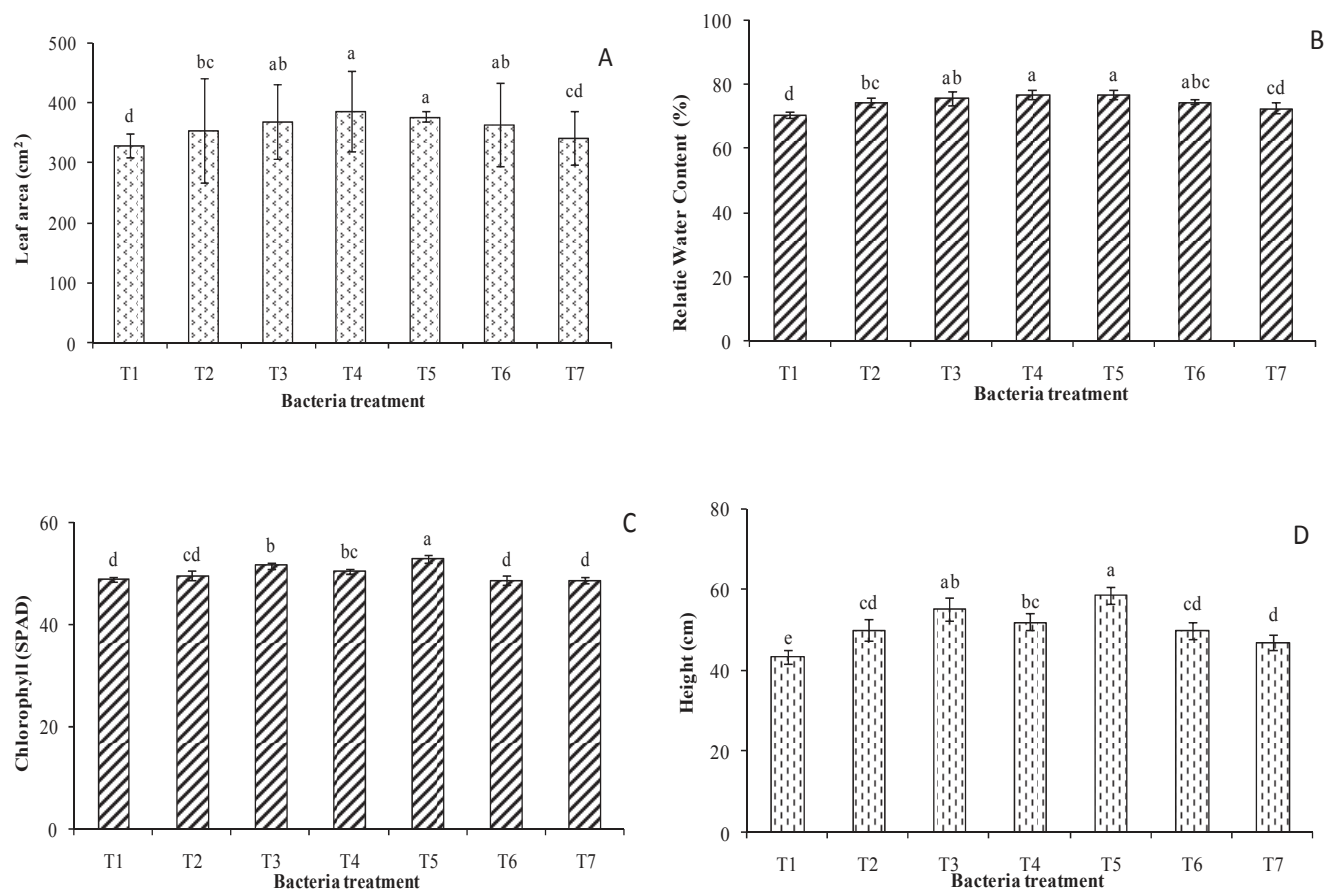

Figure 1. The effect of bacteria on the average of Leaf area (A), Relative water content (RWC) (B), Chlorophyll content (C), and Height (D) in canola (B. napus L.). (T1=without bacteria inoculation, T2=strain Sm29, T3=strain Sm103, T4=strain Rlp307, T5=strain Rlp281, T6=strain Rlp258, T7=strain Rlp266). Means in each column with at least one similar letters are not significantly different at the $5 \%$ probability level using Duncan Multiple Range Test (DMRT).

\subsection{The effect of PGPR on plant height under salinity} stress

Comparing of mean data through Duncan Multiple Range Test (DMRT) in the probability level of 5\% revealed that the highest plant height was obtained in S0 (control) followed by S1 (low salinity), S2 (moderate salinity), and $\mathrm{S} 3$ (high salinity), respectively, by $66.69,54.5,46.3$ and $36.6 \mathrm{~cm}$ (Table 4).
All examined bacteria caused significant increase in plant height compared to the control by 35.17 , $27.12,19.9,15.4,14.94$ and $8.5 \%$, respectively, in T5, T3, T4, T2, T6, and T7 (Figure 1-D). Based on ANOVA analysis for interaction effect of bacterium and salinity, the highest and the lowest value of plant height were observed in $\mathrm{T} 5 \mathrm{~S} 0$ and $\mathrm{T} 1 \mathrm{~S} 3$ treatments, respectively (Table 5). 
Table 5. The comparison of mean for the interaction effects of salinity stress and bacteria treatments on morphophysiological characteristics and nutrient concentrations in canola (B. napus L.).

\begin{tabular}{|c|c|c|c|c|c|c|c|c|c|}
\hline Treatment & $\begin{array}{c}\text { Leaf area } \\
\left(\mathrm{cm}^{2}\right)\end{array}$ & RWC (\%) & $\begin{array}{l}\text { SPAD } \\
\text { Index }\end{array}$ & $\begin{array}{l}\text { Height } \\
(\mathrm{cm})\end{array}$ & $\begin{array}{l}\text { Dry Weight } \\
\text { of Shoot }(\mathrm{g})\end{array}$ & $\begin{array}{c}\text { Dry Weight } \\
\text { of Root }(\mathrm{g})\end{array}$ & $\mathrm{R} / \mathrm{S}$ & $\mathrm{P}(\%)$ & K (\%) \\
\hline T1S0 & $390^{\mathrm{cec}}$ & $81^{\mathrm{cce}}$ & $43.1^{1}$ & $52^{\mathrm{chh}}$ & $22.8^{\mathrm{e}}$ & $2.26^{g-k}$ & $0.099^{\mathrm{e}-\mathrm{g}}$ & $0.18^{\mathrm{de}}$ & $1.87^{\mathrm{h}}$ \\
\hline T2S0 & $440^{\mathrm{ab}}$ & $83.3^{\mathrm{a}-\mathrm{c}}$ & $44.6^{j-1}$ & $68.5^{\mathrm{b}}$ & $24.1^{\mathrm{d}}$ & $3^{\mathrm{de}}$ & $0.126^{\mathrm{b}}$ & $0.189^{\mathrm{cd}}$ & $2.03^{\mathrm{e}-\mathrm{h}}$ \\
\hline T3S0 & $463^{\mathrm{a}}$ & $86.5^{\mathrm{ab}}$ & $45.9^{i-k}$ & $75^{\mathrm{b}}$ & $25.5^{\mathrm{bc}}$ & $3.9^{\mathrm{ab}}$ & $0.15^{\mathrm{a}}$ & $0.248^{\mathrm{a}}$ & $2.18^{\mathrm{ch}}$ \\
\hline T4S0 & $473^{\mathrm{a}}$ & $87.2^{\mathrm{ab}}$ & $46.5^{\mathrm{h}-\mathrm{j}}$ & $70.6^{\mathrm{b}}$ & $26.4^{\mathrm{b}}$ & $4.1^{\mathrm{a}}$ & $0.15^{\mathrm{a}}$ & $0.239^{\mathrm{ab}}$ & $2.1^{\mathrm{d}-\mathrm{h}}$ \\
\hline T5S0 & $479^{\mathrm{a}}$ & $87.8^{\mathrm{a}}$ & $47.4^{g-i}$ & $83.3^{\mathrm{a}}$ & $28.4^{\mathrm{a}}$ & $3.5^{\mathrm{bc}}$ & $0.125^{\mathrm{b}}$ & $0.226^{\mathrm{b}}$ & $2.17^{\mathrm{chh}}$ \\
\hline T6S0 & $476^{\mathrm{a}}$ & $80.6^{\mathrm{c}-\mathrm{f}}$ & $43.5^{\mathrm{k} 1}$ & $57.3^{\mathrm{ce}}$ & $25.9^{\mathrm{b}}$ & $3.16^{\mathrm{cd}}$ & $0.122^{\mathrm{bc}}$ & $0.225^{\mathrm{b}}$ & $1.86^{\mathrm{h}}$ \\
\hline T7S0 & $401^{b-d}$ & $82.4^{b-d}$ & $43.3^{\mathrm{kl}}$ & $60^{c}$ & $24.6^{\mathrm{cd}}$ & $2.3^{\mathrm{g}-\mathrm{j}}$ & $0.094^{\mathrm{f}-\mathrm{h}}$ & $0.179^{\mathrm{de}}$ & $1.95^{\mathrm{gh}}$ \\
\hline T1S1 & $375^{\mathrm{c}-\mathrm{g}}$ & $75.6^{\mathrm{e}-\mathrm{i}}$ & $47^{g-i}$ & $49.3^{\mathrm{e}-\mathrm{j}}$ & $19.6^{\mathrm{h}-\mathrm{j}}$ & $1.9^{\mathrm{j}-\mathrm{m}}$ & $0.098^{\mathrm{e}-\mathrm{g}}$ & $0.166^{\mathrm{fg}}$ & $2^{\mathrm{f}-\mathrm{h}}$ \\
\hline $\mathrm{T} 2 \mathrm{~S} 1$ & $380^{\mathrm{c}-\mathrm{f}}$ & $77.8^{\mathrm{chh}}$ & $47.2^{g-i}$ & $55.3^{\mathrm{c}-\mathrm{g}}$ & $22^{e f}$ & $2^{i-m}$ & $0.09^{\mathrm{g}-\mathrm{i}}$ & $0.171^{\mathrm{ef}}$ & $2.16^{\mathrm{ch}}$ \\
\hline $\mathrm{T} 3 \mathrm{~S} 1$ & $395^{\mathrm{cd}}$ & $77^{\mathrm{d}-\mathrm{h}}$ & $49.6^{\mathrm{e}-\mathrm{g}}$ & $57^{c-f}$ & $22.5^{\mathrm{e}}$ & $2.7^{\mathrm{e}-\mathrm{g}}$ & $0.119^{b-d}$ & $0.206^{\mathrm{c}}$ & $2.34^{\mathrm{a}-\mathrm{g}}$ \\
\hline $\mathrm{T} 4 \mathrm{~S} 1$ & $402^{\mathrm{bc}}$ & $80.5^{\mathrm{c}-\mathrm{f}}$ & $48.4^{e^{-i}}$ & $53^{\mathrm{c} g \mathrm{~g}}$ & $23.2^{\mathrm{de}}$ & $2.8^{\mathrm{d}-\mathrm{f}}$ & $0.12^{\mathrm{b}-\mathrm{d}}$ & $0.194^{c d}$ & $2.26^{\mathrm{b}-\mathrm{g}}$ \\
\hline T5S1 & $373^{\mathrm{c}-\mathrm{g}}$ & $79.2^{\mathrm{c}-\mathrm{g}}$ & $49.6^{\mathrm{e}-\mathrm{g}}$ & $58.3^{\mathrm{cd}}$ & $25.8^{\mathrm{b}}$ & $2.5^{\mathrm{f}-\mathrm{g}}$ & $0.098^{\mathrm{e}-\mathrm{g}}$ & $0.183^{\text {de }}$ & $2.26^{\mathrm{b}-\mathrm{g}}$ \\
\hline T6S1 & $372^{\mathrm{c}-\mathrm{g}}$ & $78^{\mathrm{ch}}$ & $47.7^{7^{g-i}}$ & $54^{\mathrm{c} g \mathrm{~g}}$ & $23^{\mathrm{de}}$ & $2.1^{\mathrm{h}-1}$ & $0.092^{\mathrm{g}-\mathrm{i}}$ & $0.179^{\mathrm{de}}$ & $2.03^{\mathrm{e}-\mathrm{h}}$ \\
\hline T7S1 & $378^{\mathrm{c}-\mathrm{f}}$ & $77.3^{d-h}$ & $46.3^{\mathrm{h}-\mathrm{j}}$ & $54.6^{\mathrm{c}-\mathrm{g}}$ & $23.2^{\mathrm{de}}$ & $2^{i-m}$ & $0.087^{\mathrm{g}-\mathrm{i}}$ & $0.165^{\mathrm{fg}}$ & $2.11^{\mathrm{d}-\mathrm{h}}$ \\
\hline T1S2 & $320^{\text {hi }}$ & $69.4^{\mathrm{j}}$ & $50.4^{\mathrm{ef}}$ & $43.6^{\mathrm{h}-\mathrm{k}}$ & $18.1^{\mathrm{kl}}$ & $1.6^{\mathrm{m}-\mathrm{o}}$ & $0.088^{\mathrm{g}-\mathrm{i}}$ & $0.157^{\mathrm{ij}}$ & $2.13^{\mathrm{d}-\mathrm{h}}$ \\
\hline T2S2 & $328^{g-i}$ & $73^{\mathrm{h}-\mathrm{j}}$ & $51.2^{\mathrm{de}}$ & $42.3^{\mathrm{i}-1}$ & $20.2^{g^{g-i}}$ & $1.6^{\mathrm{m}-\mathrm{o}}$ & $0.079^{\mathrm{i}}$ & $0.162^{\mathrm{gh}}$ & $2.26^{\mathrm{b}-\mathrm{g}}$ \\
\hline T3S2 & $353^{\mathrm{d}-\mathrm{h}}$ & $73.1^{\mathrm{h}-\mathrm{j}}$ & $53.3^{\mathrm{cd}}$ & $48.3^{\mathrm{f}-\mathrm{j}}$ & $21^{\mathrm{fg}}$ & $2.45^{\mathrm{f}-\mathrm{i}}$ & $0.116^{\mathrm{ce}}$ & $0.187^{d}$ & $2.4^{\mathrm{a}-\mathrm{e}}$ \\
\hline $\mathrm{T} 4 \mathrm{~S} 2$ & $355^{\mathrm{ch}}$ & $73.5^{\mathrm{h}-\mathrm{j}}$ & $51^{\mathrm{de}}$ & $47.6^{\mathrm{g}-\mathrm{j}}$ & $21.1^{\mathrm{fg}}$ & $2.33^{\mathrm{g}-\mathrm{j}}$ & $0.11^{\mathrm{cec}}$ & $0.178^{\mathrm{de}}$ & $2.4^{a-e}$ \\
\hline T5S2 & $344^{\mathrm{e}-\mathrm{h}}$ & $75.4^{\mathrm{f}-\mathrm{i}}$ & $55.7^{\mathrm{bc}}$ & $50.3^{\mathrm{d}-\mathrm{i}}$ & $22.6^{\mathrm{e}}$ & $2.33^{\mathrm{g}-\mathrm{j}}$ & $0.105^{\mathrm{d}-\mathrm{f}}$ & $0.173^{\text {ef }}$ & $2.33^{\mathrm{a}-\mathrm{g}}$ \\
\hline T6S2 & $330^{\mathrm{gh}}$ & $74^{g-j}$ & $49^{\text {e-h }}$ & $48.3^{\mathrm{f}-\mathrm{j}}$ & $20 . .^{\text {gh }}$ & $1.8^{\mathrm{k}-\mathrm{n}}$ & $0.087^{\mathrm{g}-\mathrm{i}}$ & $0.178^{\mathrm{de}}$ & $2.32^{\mathrm{a}-\mathrm{g}}$ \\
\hline T7S2 & $335^{\mathrm{fh}}$ & $70.4^{i-k}$ & $50.8^{\mathrm{de}}$ & $43.6^{\mathrm{h}-\mathrm{k}}$ & $20.6^{\text {gh }}$ & $1.66^{1-0}$ & $0.08^{\text {hi }}$ & $0.161^{\mathrm{hi}}$ & $2.22^{\mathrm{b}-\mathrm{h}}$ \\
\hline T1S3 & $230^{k}$ & $57.5^{\mathrm{n}}$ & $55.1^{\mathrm{bc}}$ & $29^{n}$ & $15.3^{\mathrm{m}}$ & $1.23^{\circ}$ & $0.08^{\text {hi }}$ & $0.154^{\mathrm{j}}$ & $2.27^{\mathrm{b}-\mathrm{g}}$ \\
\hline $\mathrm{T} 2 \mathrm{~S} 3$ & $266^{\mathrm{jk}}$ & $63.8 \mathrm{l}^{\mathrm{m}}$ & $55.7^{\mathrm{bc}}$ & $34.6^{1-\mathrm{n}}$ & $17.6^{\mathrm{kl}}$ & $1.33^{\text {no }}$ & $0.075^{\mathrm{j}}$ & $0.154^{i}$ & $2.38^{\mathrm{a}-\mathrm{f}}$ \\
\hline T3S3 & $264^{\mathrm{jk}}$ & $67^{1 \mathrm{k}}$ & $57.9^{\mathrm{ab}}$ & $41^{j-1}$ & $18.4^{j-1}$ & $1.86^{\mathrm{j}-\mathrm{m}}$ & $0.1^{\mathrm{d}-\mathrm{f}}$ & $0.172 \mathrm{ef}$ & $2.55^{\mathrm{a}-\mathrm{c}}$ \\
\hline $\mathrm{T} 4 \mathrm{~S} 3$ & $316^{\mathrm{hi}}$ & $67^{\mathrm{lk}}$ & $56^{\mathrm{bc}}$ & $37.3^{\mathrm{k}-\mathrm{m}}$ & $17.2^{1}$ & $1.75^{1-\mathrm{n}}$ & $0.1^{\mathrm{d}-\mathrm{f}}$ & $0.163 \mathrm{gh}$ & $2.58^{\mathrm{ab}}$ \\
\hline T5S3 & $316^{\mathrm{hi}}$ & $66.3^{\mathrm{k}-\mathrm{m}}$ & $59.2^{\mathrm{a}}$ & $43.3^{\mathrm{h}-\mathrm{k}}$ & $18.9^{\mathrm{i}-\mathrm{k}}$ & $2^{i-m}$ & $0.105^{\mathrm{d}-\mathrm{f}}$ & $0.157 \mathrm{ij}$ & $2.66^{\mathrm{a}}$ \\
\hline T6S3 & $282^{\mathrm{ij}}$ & $66.5^{\mathrm{k}-\mathrm{m}}$ & $55^{\mathrm{bc}}$ & $40.6^{j-1}$ & $18.1^{\mathrm{kl}}$ & $1.6^{\mathrm{m}-\mathrm{o}}$ & $0.088^{\mathrm{g}-\mathrm{i}}$ & $0.157 \mathrm{ij}$ & $2.35^{\mathrm{a}-\mathrm{f}}$ \\
\hline T7S3 & $256^{\mathrm{jk}}$ & $61.4^{\mathrm{mn}}$ & $54.9^{\mathrm{c}}$ & $30.6^{\mathrm{mn}}$ & $15.5^{\mathrm{m}}$ & $1.25^{\circ}$ & $0.08^{\text {hi }}$ & $0.161 \mathrm{hi}$ & $2.45^{\mathrm{a}-\mathrm{d}}$ \\
\hline
\end{tabular}

Means in each column with at least one similar letters are not significantly different at the $5 \%$ probability level using Duncan Multiple Range Test. (T1=without bacteria inoculation, T2=strain Sm29, T3=strain Sm103, T4=strain Rlp307, T5=strain Rlp281, T6=strain Rlp258, T7=strain Rlp266). Salinity stress (S0-S3: 0, 3, 6 and 9 ds/m). 

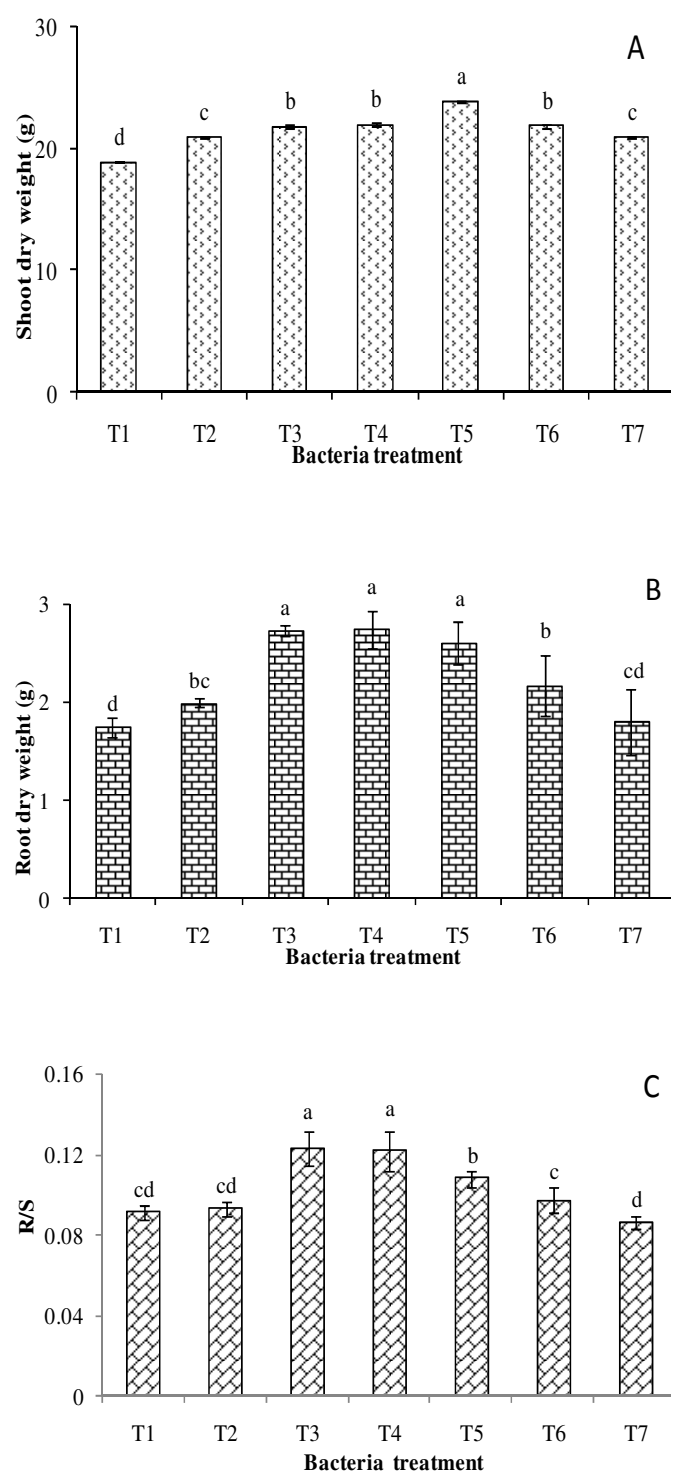

Figure 2. The effect of bacteria on the average of Dry weight of shoot (A), Dry weight of Root (B), The root to shoot dry weight ratio $(\mathrm{R} / \mathrm{S})(\mathrm{C})$ in canola $(B . n a-$ pus L.). ( $\mathrm{T} 1=$ without bacteria inoculation, $\mathrm{T} 2=$ strain $S m 29, \mathrm{~T} 3=$ strain $S m 103$, T4=strain $R l p 307$, T5=strain Rlp281, T6=strain Rlp258, T7=strain Rlp266). Means in each column with at least one similar letters are not significantly different at the $5 \%$ probability level using Duncan Multiple Range Test (DMRT).

\subsection{The effect of PGPR on shoot and root dry weight under salinity stress}

The ANOM showed that shoot and root dry weights reduced 10.25 and $27.89 \%$ in S1 treatment, 18.76 and $38.24 \%$ in S2, and 31.78 and $50.78 \%$ in S3 compared to with and without stress conditions, respectively (Table 4).

The results of bacteria inoculation revealed that the highest amount of shoot dry weight was obtained in T5 treatment with an increase of $26.16 \%$, however, the maximum value of root dry weight was achieved in T4 with an increase of $56.5 \%$ compared to the control. All of the bacteria treatments caused significant increase in shoot dry weight compared to the control (Figure 2-A, B).

Double interaction effect of bacterium and salinity revealed that the highest amount of shoot dry weight was obtained in T5 under all salinity levels. Also, root dry weight under salinity levels of S0, S1, S2, and S3, the maximum value was obtained in $\mathrm{T} 4, \mathrm{~T} 4, \mathrm{~T} 3$ and T5, respectively (Table 5).

\subsection{The effect of PGPR on root to shoot dry weight ratio $(R / S)$ under salinity stress}

Based on the analysis of variance (ANOVA), the root to shoot dry weight ratio $(\mathrm{R} / \mathrm{S})$ reduced significantly with the increase of salinity levels. The average $\mathrm{R} / \mathrm{S}$ under salinity stress of S1, S2, and S3 showed a decrease of 20,24 , and $28 \%$ compared to the control (S0), respectively, however, the decrease between S1 and S2 and also between S2 and S3 was not statistically significant (Table 4). The bacteria treatments of $\mathrm{T} 3, \mathrm{~T} 4$, and $\mathrm{T} 5$ with averages $\mathrm{R} / \mathrm{S}$ ratio of $0.123,0.122$, and 0.108 showed significant increases by $35.16,34$, and $18.68 \%$ compared to the control, respectively. T7 treatment, with a decrease of $5.49 \%$, didn't show significant difference compared to the control (Figure 2C). Also, the 
mean comparison of data showed that under all levels of salinity stress, the highest value of R/S index was found in T4 and T3 treatments (Table 5).
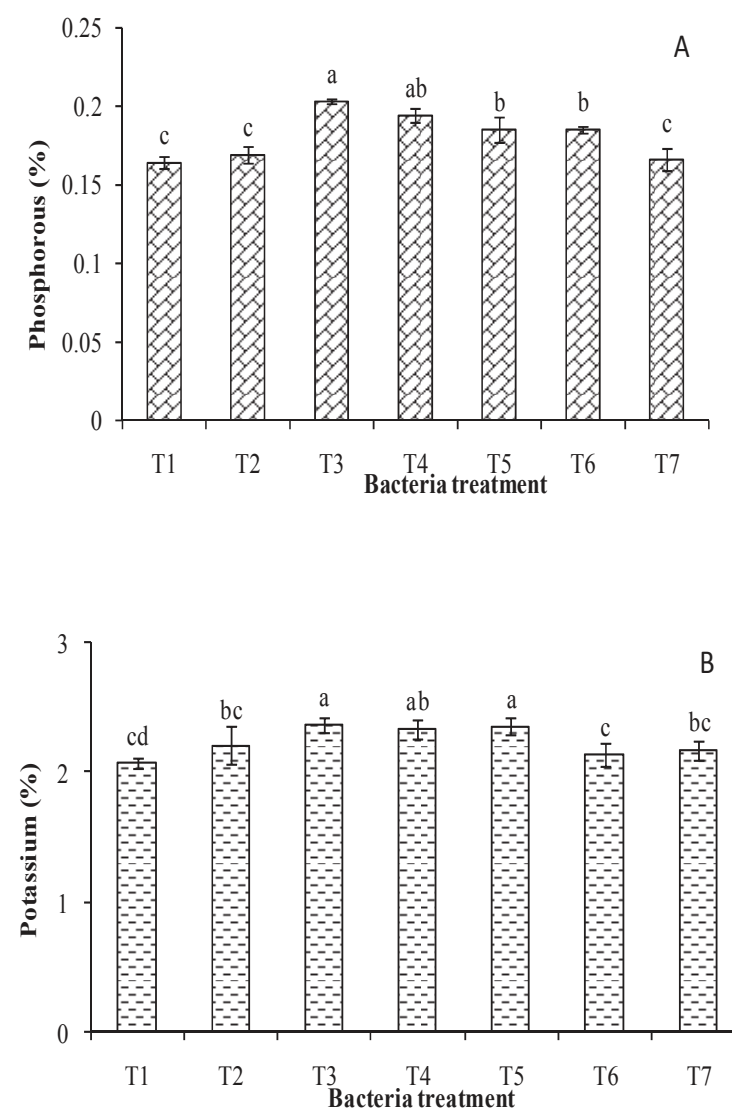

Figure 3. The effect of bacteria on the average concentration of Phosphorous (P) (A) and Potassium $\left(\mathrm{K}^{+}\right)(\mathrm{B})$ in dry shoot of canola (B. napus L.). (T1=without bacteria inoculation, T2=strain $S m 29$, T3=strain $S m 103$, T4=strain Rlp307, T5=strain Rlp281, T6=strain Rlp258, T7=strain Rlp266). Means in each column with at least one similar letters are not significantly different at the $5 \%$ probability level using Duncan Multiple Range Test (DMRT).

\subsection{The effect of PGPR and salinity stress on macro- nutrient concentration}

\subsubsection{Phosphorous (P)}

The average concentration of $\mathrm{P}$ in the shoot dropped significantly down with the increase of salinity level. The concentration of $\mathrm{P}$ in the levels of S1, S2, and $\mathrm{S} 3$ reduced by $14.28,19$, and $23.8 \%$ compared to $\mathrm{S} 0$, respectively (Table 4). The bacterial treatments of $\mathrm{T} 3, \mathrm{~T} 4, \mathrm{~T} 5$, and $\mathrm{T} 6$ with average $\mathrm{P}$ concentrations of $0.203,0.194,0.185,0.185 \%$, showed significant increase by $23.78,18.3,12.8$, and $12.8 \%$ compared to the control, respectively (Figure 3-A). Regarding to ANOM, the highest and the lowest amount of $\mathrm{P}$ was obtained from the T3S0 and T1S3 treatments, respectively. Also, in $\mathrm{S} 1$ and $\mathrm{S} 2$ levels the $\mathrm{T} 3$ treatment showed 14.4 and $3.88 \%$ increase in concentration of phosphorus compared to the control (T1S0), respectively, which represent the positive effects of this treatment under low and moderate salinity levels (Table 5).

\subsubsection{Potassium $\left(\mathrm{K}^{+}\right)$}

The highest amount of $\mathrm{K}^{+}$was obtained at $\mathrm{S} 3$ salinity level, which showed $23 \%$ of increase compared to control (S0) condition (Table 4). The bacterial treatments increased concentration of $\mathrm{K}^{+}$compared to the control, and the highest values were observed in T3, $\mathrm{T} 5$, and T4 treatments, which increased by 14.49 , 14 , and $13 \%$, respectively (Figure $3-\mathrm{B}$ ). According to the results of mean comparison data, the highest and the lowest amount of $\mathrm{K}^{+}$were found in $\mathrm{T} 5 \mathrm{~S} 3$ and T6S0 treatments, respectively (Table5). 


\section{Discussion}

In the present study, salinity stress significantly decreased mean value of leaf area and leaf relative water content. Our findings further supported by Nadeem et al. (2006) on maize, and Yildirim et al. (2008) on radish. According to the results obtained, the chlorophyll index (SPAD) was significantly increased by increasing salinity levels. This can be as a consequence of the increase in concentration or accumulation of some plastid pigments due to stress induction, and presence of magnesium in the environment as well as the rise of potassium concentration, leading to stability of the plasma membrane (Bano and Fatima 2009). Inoculation with Rhizobium strains containing ACC-deaminase activity and IAA producing property or phosphate solubilizing capability significantly increased the leaf area and relative water content of the seedlings compared to un-inoculated control. Comparing the effect of Rhizobium isolates, the T5 and T4 strains showed maximum leaf area and relative water content of the seedlings than others and un-inoculated control, respectively (Figure 1-A, B).

Studies by Karlidag et al. (2011) exhibited that the relative water content increased in the leaf samples of strawberries due to inoculation with PGPR under salinity stress. Previous studies showed that an increase in plant growth parameters following bacteria treatment can be a result of production of phytohormones and the enhancement of nutrient availability (Ghorbanpour et al., 2013; Gholami et al., 2009; Ghorbanpour et al., 2014; Ghorbanpour and Hatami, 2013; Ghorbanpour and Hatami, 2014). In another study, it has been reported that the ACC-deaminase producing bacteria leads to the enhancement of photosynthetic leaf area in plants by increasing chlorophyll content (Nadeem et al., 2006). In our study, $\mathrm{T} 5$ and $\mathrm{T} 4$ treatments were the best rhizobacterial isolates due to having combination of plant growth promoting activities. Similarly, Hassan et al. (2015) reported that the isolates having both ACC-deaminase activity and nitrogen fixing ability (i.e., WAN1) were more efficient isolates than those of having nitrogen fixing activity or ACC-deaminase activity alone. In our study, only the ACC-deaminase producing strains (T3, T4 and T5) showed significant increase in chlorophyll content compared to the control (Figure 1-C). The production of ethylene under environmental stress conditions causes plant leaf senescence, therefore, microorganisms contain ACC-deaminase activity regulate the biosynthesis of ethylene through metabolizing its immediate precursor ACC into $\alpha$-ketobutyrate and ammonia, which in turn prevent the chlorophyll degradation of host plant (Mayak et al., 2004). As it appears, the growth of root is more affected than that of shoot under salinity condition. Probably the metabolic malfunction and the physiological procedures caused by the stress ethylene are more present in the root than the shoot (Mayak et al., 2004). Besides, the roots are more in touch with the saline environment than the shoots. However, decrease in the accumulation of dry substance of the root and shoot might be because of the decrease in length of the root and shoot, and degradation of proteins in the phase of seedling growth (Mayak et al., 2004). According to the results obtained, plant height, root and shoot dry weight were significantly increased upon inoculation with bacteria. Comparing the effect of Rhizobium isolates, the T5 showed maximum plant height, root and shoot dry weight than the other isolates and un-inoculated control (Figures 1-D and 2-A, B).

Studies by Viscardi et al. (2016) indicated that the tomato inoculated with selected plant growth promoting strains of A. chroococcum (67B and 76A) increased growth and biomass accumulation under salinity stress. Similarity, Banerjee et al (2017) concluded that the inoculation of rice plants with bacterial isolate namely SB5 (IAA and ammonia producing, and 
phosphate solubilizing strain) and fungal isolate SF4 (IAA and siderophore producing, and phosphate solubilizing strain) remarkably increased root and shoot length. Studies by other researchers have declared that PGPR has positive effects on root and shoot weight, plant growth and yield (Cakmakci et al., 2007; Sirohi et al., 2015). Therefore, the positive effect of these bacteria on growth of host plants is related to changes in the morphology of the root (mostly the increase of the lateral roots, the number of the absorbing cords, and the length of the root) (Cakmakci et al., 2007). Mayak et al. (2004) studied the potential of rhizospheric bacteria in increasing the durability of tomatoes under salinity stress. Results showed that bacteria treatment significantly increased fresh and dry weight of the seedlings due to reduction in ethylene content. They also reported that the increase in plant biomass under stress conditions is due to the development of the root system, which facilitates the absorption of nutrients and water.

According to the results, ACC-deaminase producing bacteria increased growth and root dry weight. In contrast, the bacteria without ACC-deaminase activity showed little effect on plant growth and dry weight root, which were consistent with the results of Siddikee et al. (2011). Also, Shaharoona et al. (2007) reported that there is a significant linear correlation between the increase of ACC-deaminase activity of the strains and the increase of root growth. On the other hand, the ACC-deaminase producing bacteria affect the growth of the root and its function through enhanced development of the root system (Shaharoona et al., 2007). It has been reported that increments in plant growth indices by PGPR strains is supposed to be linked with the ability of these strains in N2 fixation, phosphate dissolution and the production of IAA and ACC-deaminase (Hosseinzadah et al., 2011). It seems that a mixture of the above mentioned mechanisms in T5 strain treatment has been the most efficient on plant height, root and shoot dry weight of canola seedlings under salinity stress. Hassan et al. (2015) reported similar results.

Based on ANOVA results, the root to shoot dry weight ratio $(R / S)$ reduced significantly with the increase of salinity level. Application of T3, T4, and T5 significantly increased the $\mathrm{R} / \mathrm{S}$ in compared to the control (Figure 2-C). The reduction of R/S index under salinity stress can be attributed to the concentration of ACC and ethylene, which are higher in root than shoot tissue (Mayak et al., 2004). Therefore, ethylene decreases metabolic and physiological activities, and also allocates photosynthetic materials to the root. According to the results, the highest decrease was related to the low salinity and in severe stress, probably there is the osmotic balance between the water-absorbing cells and the outer environment. Increased R/S ratio under salinity stress is a stress resistance indicator. In fact, an increased functional root biomass has been reported to strengthen the root $\mathrm{Na}$ detoxification capability (Bano and Fatima, 2009). The ratio of R/S increased through inoculation with ACC-deaminase producing bacteria which represent a drop in the adverse effects of stress ethylene on the physiological and metabolic activities of these strains. These results are in agreement with Mayak et al., (2004). Also, ACC-deaminase producing bacteria increased resistance of host plants against salinity by increasing the division of photosynthetic materials towards the root via reducing the negative effects of stress ethylene on the root cells of plants under stress (Siddikee et al., 2011).

The average concentration of $\mathrm{P}$ in the shoot significantly dropped down with increasing salinity levels. The bacterial treatments increased concentration of $\mathrm{P}$ in comparison to the control. Our results also showed that inoculation by ACC-deaminase producing bacteria increased the concentration of phosphorus accordingly, and the highest content of $\mathrm{P}$ was observed in $\mathrm{T} 3$ 
treatment (ACC-deaminase producing and phosphate solubilizing strain) (Figure 3-A). It seems that ACCdeaminase producing bacteria increase the solubility or absorption of $\mathrm{P}$, however, the mechanisms have not been understood yet (Mayak et al., 2004). Also, Hassan et al. (2015) concluded that ACC-deaminase producing rhizobacteria increase the mobility and availability of plant nutrients in the soil, and as a result increases the nutrient uptake of the wheat plants. The concentration of $\mathrm{P}$ didn't show a significant increase in T2 (Phosphate solubilizing strain) in comparison with the control, which is probably due to instability of the solved P in the environment (Rengel, 2008).

As for the T4 treatment (ACC-deaminase and IAA producing strain) it can be stated that with increase of the number of the absorbing cords of the root, the surface of the root increases 8-15 times more and, therefore, enough volume of the soil around the root is occupied by the root, only a small amount of this volume has a role in yielding low mobility elements like $\mathrm{K}^{+}$ and $\mathrm{P}$ (Baset Mia et al., 2010). About the T5 treatment (ACC-deaminase, IAA producing and solubilizing mineral insoluble P) we can state that, the amount of dry material was high, therefore, because of the dilution effect, the concentration of $\mathrm{P}$ declined compared to T3 treatment. However, in T6 treatment, $\mathrm{P}$ concentration was significantly increased. Cumming et al. (2015) stated that the PGPR play a significant role in producing a suite of compounds that weather minerals in the rhizosphere, which establishes their functional role as "phosphate solubilizing bacteria". Additionally, PGPR may stimulate exudation of compounds by their host plants capable of altering nutrient disequilibria, which could also play a role in altering nutrient solubility equilibria in the rhizosphere.

Under salinity stress, the amount of $\mathrm{K}^{+}$in canola plants was significantly increased. However, the bacterial treatments increased the concentration of $\mathrm{K}^{+}$ compared to the control (Figure 3-B). Gholami and
Rahemi (2010) showed that the amount of $\mathrm{K}^{+}$increased significantly in shoot with increasing drought stress, adjusting the osmotic pressure and stomatal control. According to our results, inoculation with ACC-deaminase producing bacteria (i.e., T5, T3 and T4) was more efficient in increasing $\mathrm{K}^{+}$compared to the control. Yue et al. (2007) reported that the inoculated ACC-deaminase producimg strains showed high increase in $\mathrm{K}^{+}$and low in $\mathrm{Na}^{+}$compared to the control. The increase in the accumulation of $\mathrm{K}^{+}$following bacterial treatments can probably be due to the fact that PGPR (ACC-deaminase producing bacteria) changes the selectivity of $\mathrm{Na}^{+}$and $\mathrm{K}^{+}$under salinity stress, and by limiting the absorption of $\mathrm{Na}^{+}$they increase the absorption of $\mathrm{K}^{+}$ meaningfully (Hamdia et al., 2004). Also, the preferred accumulation of $\mathrm{K}^{+}$in the leaves can be a result of the activities of membrane, resulting in excretion of proton from the roots (Karlidag et al., 2011).

\section{Conclusions}

Salinity stress lead to a significant decline in all of the morpho-physiological characteristics (except for the chlorophyll and potassium concentration) compared to the control. Inoculation with Rhizobium ACCdeaminase-producing bacteria resulted in increase in all of the growth indices (especially plant height, root and shoot dry weight) through reducing the adverse effects of salinity, compared to the control. This positive effect was more noticeable along with other growth promoting characteristics such as IAA production and phosphate solubilizing capability as well as ACC-deaminase activity. In general, it can be concluded that using the Rhizobium strains which have a combination of growth promoting characteristics (e.g. T5 treatment) was more efficient in increasing the growth and performance of the canola plant than the others. This may be due to nutritional balance occurred in this treatment, and is therefore introduced as 
the best Rhizobium growth promoting inoculums for canola plants under salinity stress. The results from this study confirm that in order to move toward sustainable agriculture, using local bacterial inoculums can be environmentally friendly method to improve both the growth and productivity of the plants under salinity stress.

\section{References}

Alikhani, H. 2004. Investigation the potential use of indigenous Rhizobium strains as Plant Growth Promoting Rhizobacteria (PGPR) and determine the effects of superior stains on growth parameters of wheat, corn and alfalfa, $\mathrm{PhD}$ thesis. Tehran University.

Banerjee, A. Donald, A. Joshi, S.R. 2017. Native microorganisms as potent bioinoculants for plant growth promotion in shifting agriculture (Jhum) systems. J. Soil Sci. Plant Nutr. 17, 127-140.

Bano, A., Fatima, M. 2009. Salt tolerance in Zea mays L. following inoculation with Rhizobium and Pseudomonas. Biol. Fertil. Soils. 45, 405-413.

Baset Mia, M.A., Shamsuddin, Z.H., Maziah, M. 2010. Use of Plant Growth Promoting Bacteria in Banana: A NewInsight for Sustainable Banana Production. Int. J. Agr. Biol. 12, 459-467.

Bertamini, M., Zulini, L., Nedunchezhian, K. 2006. Effect of water deficit on photosynthetic and other physiological response in grapevine (Vitis Viniera L. cv.Riesling) plants. Photosynthetica. 44, 151-154.

Cakmakci, R., Erdog, M.U., Donmez, M.F. 2007. The influence of plant growth-promoting rhizobacteria on growth and enzyme activities in wheat and spinach plants. J. Plant Nutr. Soil Sci. 170, 288-295.
Chi, F., Shen, S.H., Cheng, H.P., Jing, Y.X., Yanni, Y.G., Dazzo, F.B. 2005. Ascending migration of endophytic rhizobia, from roots to leaves, inside rice plants and assessment of benefits to rice growth physiology. Appl. Environ. Microbiol. 71, 7271-7278.

Cumming, J.R., Zawaski, C. Desai, Collart, S. 2015. Phosphorus disequilibrium in the tripartite plant ectomycorrhiza- plant growth promoting rhizobacterial association. J. Soil Sci. Plant Nutr. 15, 464-485.

Gholami, M., Rahemi, M. 2010. Effect of water stress and recovery on water status and osmotic adjustments of miniature rose meshkinjan. Res. J. inviron. sci. 4, 288-293.

Gholami, S., Shahsavani, A., Nezarat, S. 2009. The Effect of Plant Growth Promoting Rhizobacteria (PGPR) on Germination, Seedling Growth and Yield of Maize. World Academy of Science, Eng. Technol. 49, 19-24.

Ghorbanpour, M., Hatami, M., Khavazi, M. 2013. Role of plant growth promoting rhizobacteria on antioxidant enzyme activities and tropane alkaloids production of Hyoscyamus niger under water deficit stress. Turkish Journal of Biology. 37, 350-360.

Ghorbanpour, M., Hosseini, N., Khodae-Motlagh, M., Solgi, M. 2014. The effects of inoculation with pseudomonads rhizobacteria on growth, quantity and quality of essential oils in sage (Salvia officinalis L.) plant. Journal of Medicinal Plants. 52, 89-100.

Ghorbanpour, M., Hatami, M. 2013. PGPR strains affect seedling vigor index and seed secondary metabolites accumulation of black henbane under drought stress. Trakia Journal of Sciences. 2, 135-143. 
Ghorbanpour, M., Hatami, M. 2014. Biopriming of Salvia officinalis L. seed with plant growth promoting rhizobacteria (PGPRs) changes the invigoration and primary growth indices. Journal of Biological and Environmental Sciences. 8, 29-36.

Gupta, P.K., 2000. Soil, plant, water and fertilizer analysis. Agrobios. pub. Bikaner, India.

Hamdia, M.A, Shaddad, M.A.K., Doaa, M.M. 2004. Mechanisms of salt tolerance and interactive effects of Azospirillum brasilense inoculation on maize cultivars grown under salt stress conditions. Plant. Growth. Regul. 44, 165-174.

Hassan, W. Hussain, M. Bashir, S. Shah, A.N., Bano, R. David, J. 2015. ACC-deaminase and/or nitrogen fixing rhizobacteria and growth of wheat (Triticum Aestivum L.). J. Soil Sci. Plant Nutr. 15, 232-248.

Hosseinzadah, F., Satei, A., Ramezanpour, M.R. 2011. Effects of Mycorhiza and Plant Growth Promoting Rizobacteria on Growth, Nutrients Uptake and Physiological Characteritics in Calendula officinalis L. Middle-East. J. Sci. Res. 8, 947-953.

Hussain, M.B., Mehboob, I., Zahir, Z.A., Naveed, M., Asghar, H.N. 2009. Potential of Rhizobium spp. for improving growth and yield of rice (Oryza sativa L.). Soil. Environ. 28, 49-55.

Jeon, J.S., Lee, S.S., Kim, H.Y., Ann, T.S., Song, H.G. 2003. Plant growth promoting in soil by some inoculated microorganism. J. Microbiol. 271-276.

Karlidag, H., Esitken, A., Yildirim, E., Figen-Donmez, M., Turan, M. 2011. Effects of Plant Growth Promoting Bacteria on yield, growth, leaf water content, membrane permeability and ionic composition of strawberry under saline conditions. J. Plant Nutr. 34, 34-45.

Matiru, V.N., Dakora, F.D. (2004) Potential use of rhizobial bacteria as promoters of plant growth for increased yield in landraces of African cereal crops. Afr. J. Biotechnol. 3, 1-7.
Mayak, S., Tirosh, T., Glick, B.R. 2004. Plant growthpromoting that confer resistance to water stress in tomatoes and peppers. Plant Science. 166, 525530.

Ministry of Agriculture, 2012. All letters agricultural products, Volume 1, crops, crop year 2009-2010.

Nadeem, S.M., Hussain, I., Naveed, M., Asghar, H.N., Zahir, Z.A., Arshad, M. 2006. Performance of Plant Growth Promoting Rhizobacteria Containing ACC-Deaminase Activity for Improving Growth of Maize under Salt-Stressed Conditions. Pakistan. J. Agr. Sci. 43, 121- 114.

Patten, C.L., Glick, B.R. 2002. Role of pseudomonas putida indole acetic acid in development of host plant root system. Appl. Environ. Microbiol. 68 3795-3801.

Penrose, D.M., Glick, B.R. 2001. Levels of ACC and related compounds in exudates and extracts of canola seeds treated with ACC deaminase-containing plant growth promoting bacteria. Can. J. Microbiol. 47, 368-372.

Piranooshe, H., Emam, I., Jamali, R. 2011. Comparison of bio-fertilizers with chemical fertilizers on growth, yield and oil content of sunflower ( $\mathrm{He}$ lianthus nnuss L.) at different levels of drought stress. J. Agr. Ecol. 2, 492- 501.

Rengel, Z. 2008. Bioavailability of phosphorus and micronutrients in the soil-plant-microbe continuum. J. Soil Sci. Plant Nutr. 8, 84-91.

Shaharoona, B., Jamro, G.M., Zahir, Z.A., Arshad, M., Memon, K.S. 2007. Effectiveness of various Pseudomonas spp. and Burkhaldaria caryophylli containing ACC-deaminase for improving growth and yield of wheat (Triticum aestivum L.). J. Microbiol. Biotechnol. 17, 1300-1307.

Shakhavat, M. 2007. Potential use of Rhizobium spp. to improve growth of non-nitrogen fixing plants. Master's Thesis, Swedish University of Agricultural Sciences, Department of Soil Sciences P.O. Box 7014. 
Sirohi, G. Upadhyay, A. Shankar Srivastava, S. Srivastava, P. 2015. PGPR mediated Zinc biofertilization of soil and its impact on growth and productivity of wheat. J. Soil Sci. Plant Nutr. 15, 202-216.

Siddikee, A., Glick, B.R., Chauhan, S., Yim, W., Sa, T. 2011. Enhancement of growth and salt tolerance of red pepper seedlings (Capsicum annuиm L.) by regulating stress ethylene synthesis with halotolerant bacteria containing 1-aminocyclopropane-1-carboxylic acid deaminase activity. Plant. Physiol. Biochem. 49, 427- 434.

Singh, R.K., Mishra, R.P.N., Jaiswal, H.K. 2005. Role of rhizobial endophytes as nitrogen fixer in promoting plant growth and productivity of Indian cultivated upland rice (Oryza sativa L.) plants. In: Biological Nitrogen Fixation, Sustainable Agriculture and the Environment. Springer, the Netherland. Pp: 289-291.
Sessitsch, A., Howieson, J.G., Perret X, Antoun H, Martinez-Romero E (2002) Advances in Rhizobium research. Crit. Rev. Plant Sci. 21, 323-378.

Viscardi, S. Ventorino, V. Duran, P. Maggio, A. De Pascale, S. Mora, M. L., Pepe, O. 2016. Assessment of plant growth promoting activities and abiotic stress tolerance of Azotobacter chroococcum strains for a potential use in sustainable agriculture. J. Soil Sci. Plant Nutr. 16, 848-863.

Yildirim, E., Figen-Donmez, M., Turan, M. 2008. Mitigation of salt stress in radish (Raphanus Sativus L.) by plant growth promoting rhizobacteria. Roumanian Biotechnol. Lett. 13, 3933-3943.

Yue, H., Mo, W., Li, C., Zheng, Y., Li, H. 2007. The salt stress relief and growth promotion effect of RS-5 on cotton. Plant Soil. 297,139-145. 